\title{
Ammonia volatilization from Nitrogen topdressing fertilization in second-crop corn cultivated under two management systems
}

César Ferreira Santos ${ }^{1}$

Sheila Isabel do Carmo Pinto²

Konrad Passos e Silva ${ }^{3}$

Paulino da Cunha Leite ${ }^{4}$

Vagner Aparecido Vitor ${ }^{5}$

\section{Abstract}

Controlled-release fertilizers are possible strategies to reduce losses through fertilization and increase nitrogen $(N)$ use efficiency. In this context, this study aimed to evaluate the efficiency of $N$ sources applied to second-crop corn cultivation. The experiment was carried out in a randomized block design in a $2 \times 4$ factorial scheme. Two cultivation systems (conventional and no-tillage) and four $\mathrm{N}$ fertilizers (urea pearls pure, urea $+\mathrm{Cu}+\mathrm{B}$, NBPT-treated urea and complex mineral fertilizer) with four replications were studied. Losses of $\mathrm{N}-\mathrm{NH}_{3}$ by volatilization were evaluated up to 14 days after corn $\mathrm{N}$ fertilization. The data were subjected to analysis of variance and the means were grouped by the ScottKnott test at 5\% probability. Under the conditions in which the study was carried out, it was observed that urea pearls pure was the least efficient $\mathrm{N}$ fertilizer in restricting $\mathrm{N}-\mathrm{NH}_{3}$ through volatilization losses. The most efficient fertilizer was NBPT-treated urea. Losses of $\mathrm{N}^{-\mathrm{NH}_{3}}$ by volatilization in the no-tillage system were higher than in the conventional cultivation system.

Keywords: Nitrogen. Urea. Fertilizing.

\section{Introduction}

Worldwide, the cultivation of corn is largely carried out to produce corn-based products. Since corn productivity increases with the application of additional doses of nitrogen $(\mathrm{N})$, it considerably increases the consumption of such fertilizers (ARGENTA; SILVA, 2003). The use of $N$ fertilizers has increased over the years, especially in developing countries such as Brazil. However, the efficiency in the use of $\mathrm{N}$ by crops has contrasting values of around $50 \%$ related to the total applied in the soil due to large losses (LAMA, 2012). Among the main processes of $\mathrm{N}$ losses are volatilization, nitrification and denitrification, which contribute to the release of $\mathrm{NH}_{3}, \mathrm{~N}_{2} \mathrm{O}$ and $\mathrm{N}_{2}$ into the atmosphere (FOOD AND AGRICULTURE ORGANIZATION OF THE UNITED NATIONS - FAO, 2001; SHAVIV, 2005; TRENKEL, 2010).

1 Universidade Federal de Lavras (UFLA), Departamento de Ciência do Solo, doutorando em Ciência do Solo, Departamento de Ciência do Solo-UFLA.agronomocesar.santos@gmail.com. Laboratório de Corretivos e Fertilizantes-DCS, Campus UFLA, Lavras (MG). CEP: 37.200-000. 2 Instituto Federal de Minas Gerais (IFMG), Campus Bambuí, Departamento de Ciências Agrárias, professora. sheila.isabel@ifmg.edu.br. 3 Instituto Federal de Minas Gerais (IFMG), Campus Bambuí, Departamento de Ciências Agrárias, técnico em Agropecuária. konrad.silva@ ifmg.edu.br.

4 Instituto Federal de Minas Gerais (IFMG), Campus Bambuí, Departamento de Ciências Agrárias, professor. paulino.leite@ifmg.edu.br.

5 Agropecuária Piunhi (AP), consultor agrícola. vagnervitorconsultoria@hotmail.com. 
Urea stands out as the main mineral source of $\mathrm{N}$ fertilizers used in agriculture, due to its affordable price and high $\mathrm{N}$ content (SOUZA et al., 2017), which makes transportation and storage economical. However, the application of urea without soil incorporation can generate significant $\mathrm{N}$ losses due to ammonia volatilization. In this case, the losses of ammonia $\left(\mathrm{NH}_{3}\right)$ can reach up to $80 \%$ with the superficial application in no-tillage systems and up to $30 \%$ in conventional cultivation systems (LARA CABEZAS, 1998).

Lately, in response to the widespread use of the no-tillage system and the changes in soil management, $\mathrm{N}$ losses through volatilization have been intensified due to mulching. According to Cancellier et al. (2016), this is due to the higher activity of the enzyme urease and the lower diffusion of urea into the soil, leading to a localized increase in soil $\mathrm{pH}$, causing ammonium to transform into ammonia. In the case of no-tillage systems, the non-revolving of the soil at the time of lime application makes the surface layer of the soil alkaline, favoring the loss of $\mathrm{N}$ by ammonia volatilization. Although the volatilization losses are higher in no-tillage systems, there are numerous benefits involved in this kind of cultivation, such as soil temperature, increases in moisture and organic matter contents, nutrient cycling, reduction of soil compaction, minimizing the erosion process. Thus, technologies to increase fertilizer utilization efficiency ought to be improved, especially regarding $\mathrm{N}$ fertilizers.

Several techniques can be used to reduce $\mathrm{N}$ losses and to increase the efficiency in the use and recovery of $\mathrm{N}$ applied via fertilizer. For example, the use of slow or controlled-released fertilizers can increase their application efficiency, since they are covered or encapsulated by substances that cause nutrients to be gradually released, or have substances that prevent some stage of $\mathrm{N}$ transformation after application in the soil (TRENKEL, 2010). Thus, $\mathrm{N}$ losses by volatilization are minimized and the $\mathrm{N}$ availability follows the plant needs.

This technology has been commercially produced since 1961 (TRENKEL, 2010). However, the cost for its production is still high (MAESTRELO et al., 2014), limiting their use in low value-added crops. The combination of the low cost of sulfur coating and its uniform distribution in the granule generates more competitive and efficient fertilizers that improve $\mathrm{N}$ utilization by reducing volatilization Iosses (CANCELLIER et al., 2016). In addition, this technology makes it possible to increase the yield of agricultural machinery, since fertilization can be performed in a single application and without the need for incorporation.

In this context, this study aimed to evaluate ammonia losses by volatilization of urea, stabilized and slow release nitrogen fertilizers when applied to conventional tillage and no-tillage systems in second-crop corn cultivation.

\section{Material and methods}

The experiment was carried out in Medeiros, state of Minas Gerais, in a relief characterized as soft undulating. The soil of the area is characterized as distroferric red latosol (EMBRAPA, 2013).

The experiment was carried out using a randomized block design in a $4 \times 2$ factorial scheme, with four $\mathrm{N}$ sources (urea pearls pure $(46 \% \mathrm{~N})$, urea $+\mathrm{Cu}+\mathrm{B}(0.3 \% \mathrm{~B} ; 0.3 \% \mathrm{Cu} ; 43 \% \mathrm{~N})$, NBPTtreated urea $(46 \% \mathrm{~N})$ and complex mineral fertilizer $\left(221 \% \mathrm{~N} ; 2 \% \mathrm{P}_{2} \mathrm{O}_{5} ; 9 \% \mathrm{~K}_{2} \mathrm{O} ; 5 \% \mathrm{~S} ; 0.2 \% \mathrm{~B}\right.$ and $0.2 \% \mathrm{Zn}$ ) and two cultivation systems (no tillage and conventional tillage), with 4 replications, totaling 32 experimental plots.

Each experimental plot consisted of five meter long corn lines sown manually. Collectors for $\mathrm{N}-\mathrm{NH}_{3}$ losses through volatilization were installed in the center of each experimental plot. 
The area was cultivated under two tillage systems: conventional and no-tillage. For the simulation of the conventional system, plant residues were removed from the area and the soil was revolved to approximately $20.0 \mathrm{~cm}$ deep. This operation was performed 30 days before the crop was implanted. As for the no-till plots, no intervention was carried out, since the area had already been cultivated under no-till system for eight years.

The experimental area in the previous crop was occupied by soybean. The results of the soil analysis (TABLE 1) refer to the year 2015, prior to the last soybean crop cultivation. The soybean crop was fertilized with $22.5 \mathrm{~kg} \mathrm{ha}^{-1}$ of $\mathrm{N}$ and $120.0 \mathrm{~kg}$ ha-1 of $\mathrm{P}_{2} \mathrm{O}_{5}$ using monoammonium phosphate fertilizer - MAP $\left(9.0 \% \mathrm{~N}\right.$ and $\left.48.0 \% \mathrm{P}_{2} \mathrm{O}_{5}\right)$. For second-crop corn cultivation, $200.0 \mathrm{~kg} \mathrm{ha}^{-1}$ of the formulated fertilizer 4-30-16 distributed in advance in the planting area were used.

Table 1 - Result of soil analysis $(0-20 \mathrm{~cm})$ of the experimental area (soil sampling was carried out in 2015)

\begin{tabular}{llll}
\hline \multicolumn{1}{c}{ Variable } & \multicolumn{3}{c}{ Variable } \\
\hline $\mathrm{pH}\left(\mathrm{H}_{2} \mathrm{O}\right)$ & 6.2 & $\mathrm{~V}$ & $66.2 \%$ \\
$\mathrm{P}(1)$ & $6.4 \mathrm{mg} \mathrm{dm}^{-3}$ & $\mathrm{~m}$ & $0 \%$ \\
$\mathrm{~K}^{(1)}$ & $98 \mathrm{mg} \mathrm{dm}^{-3}$ & $\mathrm{O}$ & $2.41 \mathrm{dag} \mathrm{kg}^{-1}$ \\
$\mathrm{Ca}^{(2)}$ & $2.73 \mathrm{cmol}_{\mathrm{c}} \mathrm{dm}^{-3}$ & $\mathrm{P}(\mathrm{rem})$ & $14.3 \mathrm{mg} \mathrm{L}^{-1}$ \\
$\mathrm{Mg}^{(2)}$ & $0.69 \mathrm{cmol}_{\mathrm{c}} \mathrm{dm}^{-3}$ & $\mathrm{Mn}^{(1)}$ & $12 \mathrm{mg} \mathrm{dm}^{-3}$ \\
$\mathrm{Al}^{(2)}$ & $0 \mathrm{cmol}_{\mathrm{c}} \mathrm{dm}^{-3}$ & $\mathrm{Zn}^{(1)}$ & $2.5 \mathrm{mg} \mathrm{dm}^{-3}$ \\
$\mathrm{H}+\mathrm{Al}^{(3)}$ & $1.87 \mathrm{cmol}_{\mathrm{c}} \mathrm{dm}^{-3}$ & & \\
$\mathrm{SB}$ & $3.7 \mathrm{cmol}_{\mathrm{c}} \mathrm{dm}^{-3}$ & & \\
$\mathrm{CEC}(\mathrm{t})$ & $3.7 \mathrm{cmol}_{\mathrm{c}} \mathrm{dm}^{-3}$ & & \\
$\mathrm{CEC}(\mathrm{T})$ & $5.5 \mathrm{cmol}_{\mathrm{c}} \mathrm{dm}^{-3}$ & & \\
\hline
\end{tabular}

P-K-Fe-Zn-Mn-Cu: Mehlich-1 Extractor; (2) Ca-Mg-Al: 1 mol L-1 KCl Extractor; (3) H + Al - SMP Extractor; SB $=$ Sum of Exchangeable Bases; CEC $(\mathrm{t})=$ Effective Cation Exchange Capacity; $\mathrm{CEC}(\mathrm{T})=$ Cation Exchange Capacity at $\mathrm{pH} 7.0 ; \% \mathrm{~V}=$ Base Saturation Index; $\mathrm{m}=$ Aluminum Saturation; O.M = organic matter (Oxidation with $4 \mathrm{~N} \mathrm{Na}_{2} \mathrm{Cr}_{2} \mathrm{O}_{7}+10 \mathrm{~N} \mathrm{H}_{2} \mathrm{SO}_{4}$ ); $\mathrm{P}(\mathrm{rem})=$ remaining soil phosphorus content.

Source: Elaborated by the authors (2018).

The hybrid AS1575 from Agroeste, which is characterized as medium size, resistant stalk, good stuffing, semi-grain texture used for grain production was used in this study. A plant population density of 60,000 plants ha-1 was used. To guarantee the final stand of the experiment, 120,000 plants ha-1 were sown and at 15 days after sowing (DAS) thinning was carried out, leaving the desired number of plants.

For weed control, herbicides based on Atrazine and Nicosulfuron, both selective to the crop, were applied at 30 DAS. Potassium fertilization was carried out according to soil analysis: the first application was performed at 54 DAS, applying $100.0 \mathrm{~kg} \mathrm{ha}^{-1}$ of potassium chloride fertilizer (58\% $\mathrm{K}_{2} \mathrm{O}$ ) and the second at $69 \mathrm{DAS}$, using the same source and dose. Fertilization was delayed due to the lack of significant precipitation for seed germination, which delayed the entire production process.

Nitrogen fertilization was performed on different sources of $\mathrm{N}$ (urea pearls pure, urea $+\mathrm{Cu}+\mathrm{B}$, NBPT-treated urea and complex mineral fertilizer). Nitrogen fertilization was performed on 73 DAS of second-crop corn, using $200.0 \mathrm{~kg} \mathrm{ha}^{-1}$ of $\mathrm{N}$ in a single application. This dose was converted to the collector area, so each collector base received $10.0 \mathrm{~g}$ of $\mathrm{N}$. 
Ammonia losses were quantified using the semi-open collector method developed by Nonmik (1973) and adapted by Lara-Cabezas et al. (1999).

For the evaluation of $\mathrm{NH}_{3}$ losses in the experimental plots, the bases of the chambers were installed on the same day as the $\mathrm{N}$ application. Two bases were used for each experimental plot aiming at the alternation of the chambers, so that while one base was being occupied by the chamber, the other remained exposed to the natural conditions of the environment.

The chambers were coupled to $20.0 \mathrm{~cm}$ high bases fixed at a depth of five centimeters in the soil. Two sponges were placed inside each chamber with a density of approximately $0.02 \mathrm{~g} \mathrm{~cm}^{-3}$ soaked in $40 \mathrm{~mL}$ of phosphoric acid solution $\left(60.0 \mathrm{~mL} \mathrm{~L}^{-1}\right)$ and glycerine $\left(50.0 \mathrm{~mL} \mathrm{~L}^{-1}\right)$. The sponge located at the top of the chamber was designed to prevent contamination of the lower sponge while it captured the lost ammonia (LARA CABEZAS; TRIVELIN, 1990).

After each collection, new sponges soaked in phosphoric acid and glycerin solution were placed in the lower chamber supports. Samples were collected on the first, second, third, fifth, ninth and fourteenth days after fertilization. In each collection, the sponges were placed in plastic bags and identified for further analysis.

The ammonium phosphate was extracted by 5 successive washes with distilled water. Each washing was carried out with $40.0 \mathrm{~mL}$ of water, over a porous plate Büchner funnel coupled to a kitassate by suction using a vacuum pump. After sample extraction, an aliquot of approximately 80.0 $\mathrm{mL}$ was stored.

For the distillation, $20.0 \mathrm{~mL}$ of the solution was pipetted and transferred to the digestion tube and distilled by the Kjedahl semimicro method, by adding $10.0 \mathrm{~mL}$ of $40.0 \%$ sodium hydroxide solution, and then titrating the samples with hydrochloric acid solution (MALAVOLTA et al., 1997).

The data of $\mathrm{NH}_{3}$ losses through volatilization were subjected to analysis of variance (F-Test) and the means were grouped using the Scott-Knott test at 5\% probability, using "System for Analysis of Variance" - SISVAR software (FERREIRA, 2011).

\section{Results and discussion}

Interactions between cultivation systems (no-tillage or conventional tillage) and sources of $\mathrm{N}$ used in the fertilization of second-crop corn were significant for the $\mathrm{NH}_{3}$ losses through volatilization and for the accumulated loss of $\mathrm{NH}_{3}$ in this study, period of fourteen days $(p \leq 0.05)$.

In the evaluation of $\mathrm{NH}_{3}$ losses performed one day after fertilization, the complex mineral nitrogen fertilizer presented higher ammonia loss when compared with the other $\mathrm{N}$ fertilizers, regardless of the cultivation system (Figure $1 \mathrm{~b}$ ). In the evaluation carried out on the second day after fertilization, it was observed in the no-tillage system higher ammonia losses by urea pearls pure, while in the conventional system the complex mineral nitrogen fertilizer was less efficient (Figure $1 \mathrm{a}$ ). In the evaluations performed one and two days after the application of fertilization, it was verified that the urease inhibitor fertilizer, NBPT-treated urea, was more efficient, avoiding higher volatilization ammonia losses (Figure 1), regardless of the cultivation system. 
Figure 1 - Daily losses of $\mathrm{N}-\mathrm{NH}_{3}(\%)$ after $\mathrm{N}$-fertilizers application on second-crop corn cultivation under (a) no-tillage and (b) conventional cultivation systems.

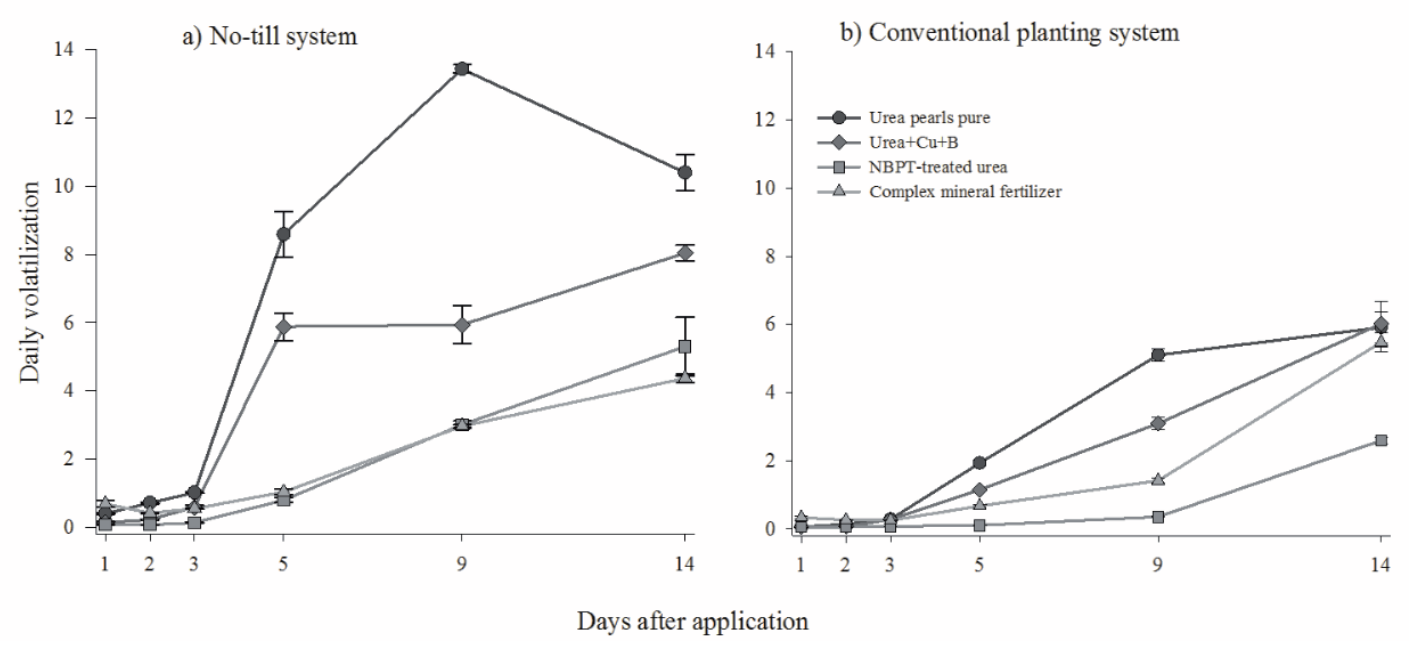

Source: Elaborated by the authors (2018).

In the evaluation performed three days after fertilization, in the no-tillage system, the source urea pearls pure had the largest ammonia losses (FIGURE 1a), while NBPT-treated urea was the most efficient source in reducing the losses. This source presented similar behavior in the conventional cultivation system (FIGURE 1 b). As for the fifth day after fertilization, it was observed that urea pearls pure provided greater losses of ammonia in both cultivation systems (FIGURE 1). In the evaluations carried out on the third and fifth days after fertilization, the source NBPT-treated urea was more efficient in avoiding larger losses of ammonia by volatilization, regardless of the cultivation system.

For the evaluation performed on the ninth day after fertilization, urea pearls pure remained less efficient in controlling ammonia losses, regardless of the cultivation system (FIGURE 1). NBPT-treated urea was the most efficient in restricting losses in the conventional tillage system (FIGURE 1 b). In the no-tillage system, both NBPT-treated urea and the complex mineral nitrogen sources were efficient (FIGURE 1a).

At fourteen days after fertilization, in the no-tillage system (FIGURE 1 a), urea pearls pure remained less efficient in controlling ammonia losses, while the sources NBPT-treated urea and complex mineral nitrogen were the most efficient in restricting losses. In the conventional tillage system, urea pearls pure, urea $+\mathrm{Cu}+\mathrm{B}$ and complex mineral nitrogen were the least efficient sources regarding the reduction of volatilization, while NBPT-treated urea was the most efficient one (FIGURE 1 b).

In general, urease inhibitor urea was more efficient in reducing ammonia losses from volatilization. In stabilized nitrogen fertilizers, such as NBPT-treated urea, the additive added to urea in the production process (urease inhibitor) promotes delayed conversion of the amide form $\left[\left(\mathrm{NH}_{2}\right)_{2} \mathrm{CO}\right]$ present in the ammonia fertilizer $\left(\mathrm{NH}_{3}\right)$, providing a decrease in volatilization (SOUZA et al., 2017). According to Cantarella (2007), NBPT inhibits urease and with consequent reduction 
of urea hydrolysis for a period that can vary from 3 to 14 days, depending on the environmental conditions at the application site.

According to Jones et al. (2007), ammonia losses from ammonia volatilization are influenced by factors related to soil temperature and humidity, relative air humidity, wind speed, rainfall, among others (WATSON et al., 2008). However, after the nitrogen fertilization of second-crop corn cultivation, no significant precipitation occurred (FIGURE 2). Only on the ninth day after fertilization, there was a precipitation of $1.4 \mathrm{~mm}$, which contributed to the peak of ammonia loss due to urea volatilization in the no-tillage system (FIGURE 1 a). This behavior did not occur in the conventional cultivation system, probably due to the rapid incorporation of the fertilizer into the soil, reducing its exposure. In the case of no-tillage, as the fertilizer is applied on the mulch, more precipitation would be necessary to incorporate it into the soil.

Figure 2 - Climate data collected five days before fertilization and during field sponge sampling.

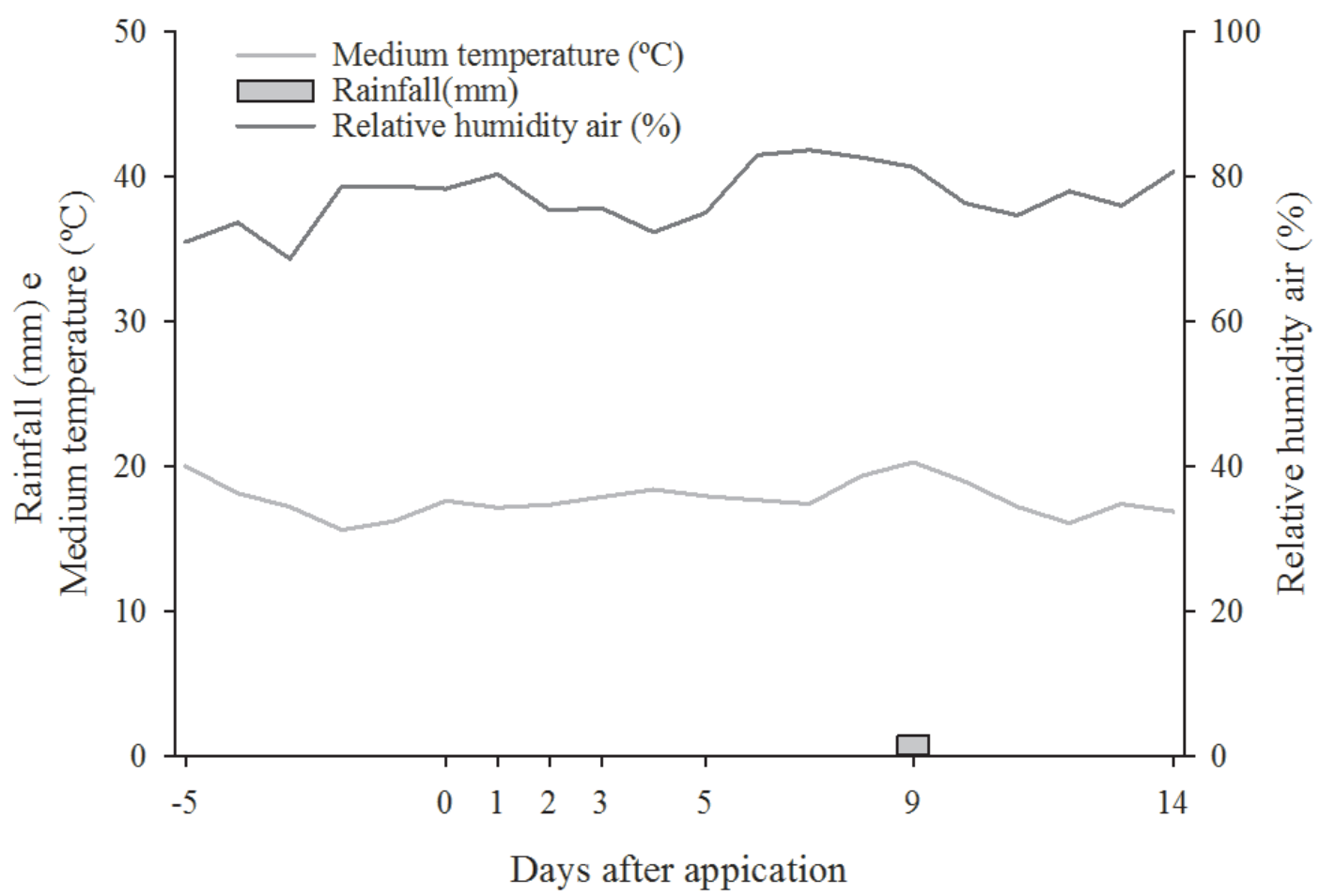

Source: Elaborated by the authors (2018).

During the experimental period, the relative humidity was prone to losses, as well as the average daily temperature, and due to the low rainfall, the loss peaks were delayed until the ninth day of evaluation (FIGURE 1).

The accumulated losses of ammonia recorded at fourteen days after fertilization are shown in Figure 3. The sequence of restriction efficiency of ammonia losses presented by the evaluated fertilizers in the conventional system followed the decreasing order: urea pearls pure $<\mathrm{urea}+\mathrm{Cu}+\mathrm{B}$ $<$ complex mineral nitrogen < NBPT-treated urea. 
Figure 3 - Accumulated $\mathrm{NH}_{3}$ losses (\% of the total applied dose) after 14 days of $\mathrm{N}$ fertilizers application in the second-crop corn cultivation.

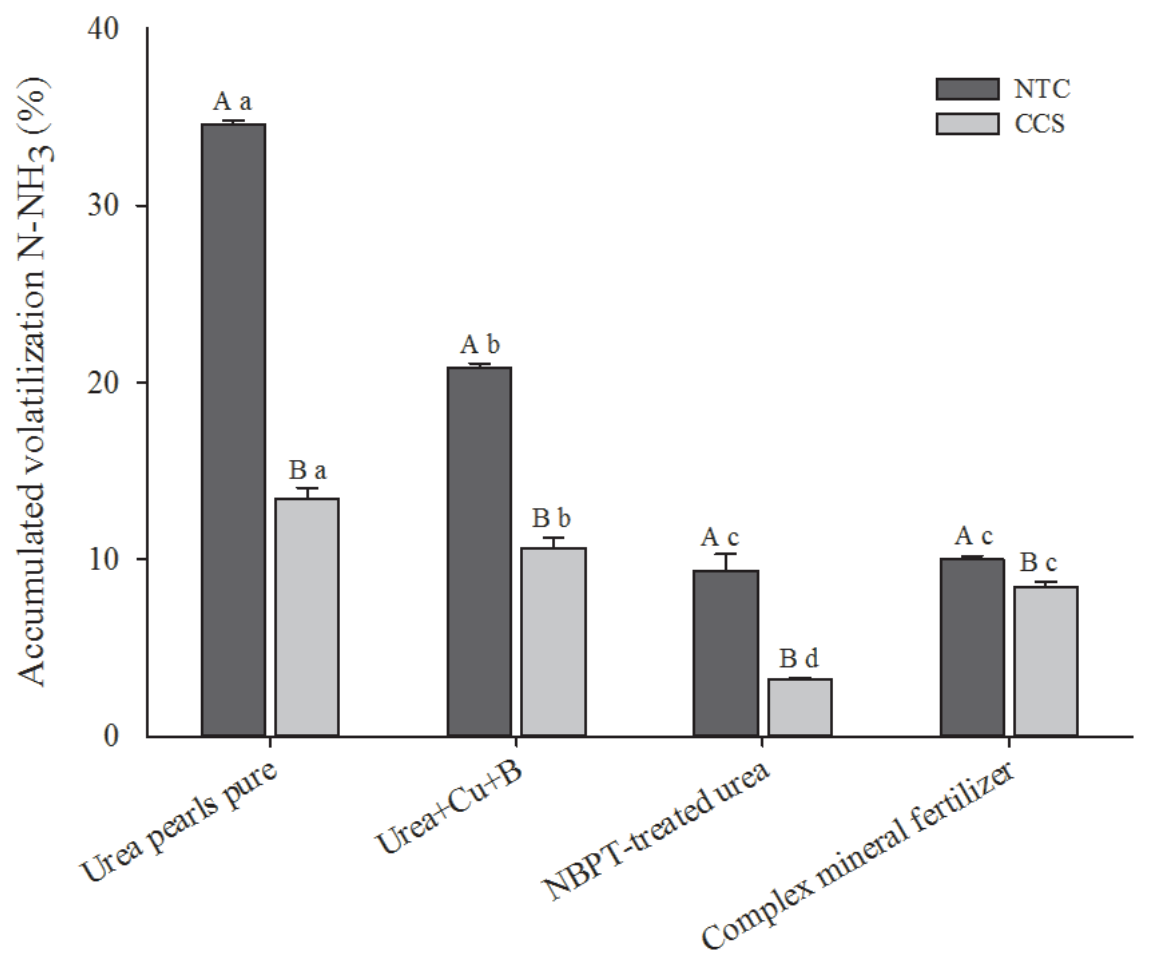

Averages followed by the same letter, upper case for different systems - NTC (no-tillage cultivation system) and CCS (conventional cultivation system), and lower case for fertilizer sources - urea pearls pure, urea $+C u+B$, NBPT-treated urea and complex mineral fertilizer - do not differ by the Scott-Knott test at 5\% probability.

Source: Elaborated by the authors (2018).

For the no-tillage system, the sequence of restriction efficiency of ammonia losses presented by the evaluated fertilizers showed the following decreasing order: urea pearls pure $<$ urea $+\mathrm{Cu}+\mathrm{B}<$ complex mineral nitrogen $=$ NBPT-treated urea (FIGURE 3).

The use of urea with urease inhibitor, NBPT-treated urea, has been shown to be efficient in reducing $\mathrm{NH}_{3}$ losses due to volatilization, and one of the main gains obtained with NBPT is the increased time to incorporate urea by rain action at depths at which it is less susceptible to volatilization losses (MIKKELSEN, 2009; DAWAR et al., 2011).

Pereira et al. (2009) evaluated the volatilization of $\mathrm{N}^{-N_{3}}$ fertilizers applied to second-crop corn using different $\mathrm{N}$ sources and found that urea with urease inhibitor reduced $\mathrm{N}$ volatilization by up to $50.0 \%$ when compared with common urea, which reflected in higher productivity.

In the no-tillage system, ammonia losses reached up to $34.55 \%$ of $\mathrm{N}$ applied in when the source used was urea pearls pure and $9.36 \%$ when the source was NBPT-treated urea (FIGURE 3). In the conventional cultivation system, the highest losses were observed when using urea pearls pure (13.41\%), and the lowest when NBPT-treated urea (3.22\%) was applied (FIGURE 3). The loss of $\mathrm{N}-\mathrm{NH}_{3}$ by urea applied to the soil surface in the no-tillage system is close to the values observed 
in southeastern Brazil, ranging from $38.0 \%$ to $78.0 \%$ of the total $\mathrm{N}$ applied to the crops (LARA CABEZAS et al., 1997; LARA CABEZAS et al., 2000; Costa et al., 2003).

The values for the extremes of losses in the no-tillage system corresponded to a lost amount of $69.1 \mathrm{~kg} \mathrm{ha}^{-1}$ (urea pearls pure) and $18.7 \mathrm{~kg} \mathrm{ha}^{-1}$ (NBPT-treated urea) of $\mathrm{N}-\mathrm{NH}_{3}$ related to the dose of $200.0 \mathrm{~kg} \mathrm{ha}^{-1}$ of $\mathrm{N}$. As for the accumulated losses of $\mathrm{N}^{-\mathrm{NH}_{3}}$ in the conventional cultivation system, it ranged between $13.41 \%$ and $3.22 \%$ of $\mathrm{N}$ applied as urea pearls pure and NBPT-treated urea, respectively (FIGURE 3). These values correspond to an amount of 26.8 and $6.4 \mathrm{~kg} \mathrm{ha}^{-1}$ of N-NH lost, relative to the total of $200.0 \mathrm{~kg} \mathrm{ha}^{-1}$ of $\mathrm{N}$ applied in the soil.

The reduction percentages of $\mathrm{N}-\mathrm{NH}_{3}$ losses by the nitrogen fertilizers when compared with urea pearls pure in the no-tillage system were: 39.7, 72.9 and $71.1 \%$ for urea $+\mathrm{Cu}+\mathrm{B}$, NBPT-treated urea and complex mineral fertilizer, respectively. The percentages of reduction of $\mathrm{N}-\mathrm{NH}_{3}$ losses by the nitrogen fertilizers when compared with urea pearls pure in the conventional cultivation system were: $20.6,76.0$ and $37.4 \%$ for urea $+\mathrm{Cu}+\mathrm{B}$, NBPT-treated urea and complex mineral fertilizer, respectively. Therefore, NBPT-treated urea obtained the largest reductions in $\mathrm{N}-\mathrm{NH}_{3}$ losses when compared with urea pearls pure.

The results of the present study show the potential of nitrogen fertilizers with urease inhibitor in reducing $\mathrm{N}-\mathrm{NH}_{3}$ losses by volatilization even when used in no-tillage cultivation systems. However, the urease inhibitor urea should be evaluated with caution, as highlighted by Otto et al. (2017), considering the price of these fertilizers in relation to urea and its effects on yield, which was not evaluated in the present study.

\section{Conclusions}

Under the conditions in which the present study was carried out, it can be concluded that urea pearls pure was the least efficient nitrogen fertilizer in the restriction of $\mathrm{N}^{-\mathrm{NH}_{3}}$ losses by volatilization. The urease inhibitor urea, NBPT-treated urea, was the most efficient source regarding the reduction of $\mathrm{N}-\mathrm{NH}_{3}$ losses by volatilization. Losses of $\mathrm{N}-\mathrm{NH}_{3}$ by volatilization in the no-tillage cultivation system were higher than in the conventional cultivation system.

\section{Volatilização de amônia por fertilizantes nitrogenados aplicados em cobertura no milho sob dois sistemas de cultivo}

\section{Resumo}

Uma das tecnologias mais promissoras para o aumento da eficiência de aproveitamento do $\mathrm{N}$ é a utilização de fertilizantes de liberação lenta ou controlada que reduzem as perdas do $\mathrm{N}$ por volatilização. Neste contexto, o trabalho teve por objetivo avaliar a eficiência de fontes nitrogenadas aplicadas na adubação de cobertura do milho safrinha. O experimento foi instalado em blocos casualizados em esquema fatorial $2 \times 4$, sendo dois sistemas de cultivo (convencional e plantio direto) e quatro fertilizantes nitrogenados aplicados em cobertura (ureia perolada, ureia $+\mathrm{Cu}+\mathrm{B}$, ureia NBPT e fertilizante complexo) e quatro repetições. Foram avaliadas as perdas de $\mathrm{N}_{-} \mathrm{NH}_{3}$ por volatilização no período de quatorze dias após a adubação nitrogenada de cobertura do milho. Os dados foram submetidos à análise de variância e as médias agrupadas pelo teste de Scott-Knott a $5 \%$ de 
probabilidade. Nas condições em que o trabalho foi desenvolvido, observou-se que a ureia perolada foi o fertilizante nitrogenado menos eficiente na restrição das perdas de $\mathrm{N}-\mathrm{NH}_{3}$ por volatilização em relação aos demais e a ureia+NBPT o mais eficiente. As perdas de $\mathrm{N}-\mathrm{NH}_{3}$ por volatilização no sistema de plantio direto foram superiores às quantificadas no plantio convencional.

Palavras-chave: Nitrogênio. Ureia. Adubação.

\section{References}

ARGENTA, G.; SILVA, P. R. F. Adubação nitrogenada em milho pelo monitoramento do nível de nitrogênio na planta por meio do clorofilômetro. Revista Brasileira de Ciência do Solo, v. 27, p. 109$119,2003$.

CABEZAS, W. A. R. L. Comportamento dos adubos nitrogenados em clima e solo de Cerrado. In: Curso sobre aspectos básicos de fertilidade e microbiologia do solo sob plantio direto, 1, 1998, Rio Verde. 06 set. 2017.

CANCELLIER, E. L.; GUELFI, D. R.; FAQUIM, V.; GONÇALVES, B. A. de; CANCELLIER, L. L.; SPEHAR, C. R. Ammonia volatilization from enhanced-efficiency urea on no-till maize in Brazilian Cerrado with improved soil fertility. Revista Ciência e Agrotecnologia, v. 40, n. 2, p. 133-144, 2016.

CANTARELLA, H. Nitrogênio. In: NOVAIS, R. F.; ALVAREZ, V. V. H.; BARROS, N. F. de; FONTES, R. L. F.; CANTARUTTI, R. B.; NEVES, J. C. L. (Ed.). Fertilidade do Solo. Viçosa-MG: Sociedade Brasileira de Ciência do Solo, 2007. 1017 p.

COSTA, M. C. G.; VITTI, G. C.; CANTARELLA, H. Volatilização de N-NH3 de fontes nitrogenadas em cana-de-açúcar colhida sem despalha a fogo. Revista Brasileira de Ciência do Solo, v. 27, n. 4, p. 631-637, 2003.

DAWAR, K.; ZAMAN, M.; ROWARTH, J. S.; BLENNERHASSETT, J.; TURNBULL, M. H. Urea hydrolysis and lateral and vertical movement in the soil: effects of urease inhibitor and irrigation. Biology and Fertility of Soils, v. 47, n. 2, p. $139-146,2011$.

EMPRESA BRASILEIRA DE PESQUISA AGROPECUÁRIA - EMBRAPA. Sistema Brasileiro de Classificação de Solos, 2017.

FERREIRA, D. F. Sisvar: a computer statistical analysis system. Ciência e Agrotecnologia, v. 35, n. 6, p. 1039-1042, 2011.

FOOD AND AGRICULTURE ORGANIZATION OF THE UNITED NATIONS. Global inventory of $\mathbf{N H}_{3}$, emissions from mineral fertilizers and animal manure applied to croplands and grasslands. Disponível em: http://www.fao.org. Acesso em: 06 out. 2017.

JONES, C. A.; KOENIG R. T.; ELLSWORTH, J. W.; BROWN, B. D. JACKSON, G. D. Management of urea fertilizer to minimize volatilization. Montana State University Extension 2007. 173 p. 
LAMA, P. I. Nitrato e amônio na solução de solo sob diferentes usos agrícolas. Viçosa: Universidade Federal de Viçosa, 2012. 43f. Dissertação Mestrado.

LARA CABEZAS, W. A. R.; KORNDORFER, G. H.; MOTTA, S. A. Volatilização de amônia-N na cultura de milho: I - Efeito da irrigação e substituição parcial da ureia por sulfato de amônio. Revista Brasileira de Ciência do Solo, v. 21, n. 3, p. 481-487, 1997.

LARA CABEZAS, W. A. R.; TRIVELIN, P. C. O.; BENDASSOLLI, J. A.; GASCHO, G. J. Calibration of a semi-open static collector for determination of ammonia volatilization from nitrogen fertilizers. Communications in Soil Science and Plant Analysis, v. 30, p. 389- 406, 1999.

LARA CABEZAS, W. A. R.; TRIVELIN, P. C. O. Eficiência de um coletor semi-aberto estático na quantificação de $\mathrm{N}-\mathrm{NH}_{3}$ volatilizado da ureia aplicada ao solo. Revista Brasileira de Ciência do Solo, Viçosa, MG, v. 14, n. 3, p. 345-352, set./dez. 1990.

LARA CABEZAS, W. A. R.; TRIVELIN, P. C. O.; KONDÖRFER, G. H.; PEREIRA, S. Balanço da adubação nitrogenada sólida e fluída de cobertura na cultura do milho em sistema de plantio direto no triângulo mineiro (MG). Revista Brasileira de Ciência do Solo, v. 24, n. 2, p. 363-376, 2000.

MAESTRELO, P. R.; BUZETTI, S.; TEIXEIRA FILHO, M. C. M.; GARCIA, C. M. P. de; RODRIGUES, M. A. C. de; LINO, A. C. M.; ANDREOTTI, M.; Aplicação de ureia revestida em cobertura no milho irrigado sob sistema de semeadura direta. Semina-Ciências Agrarias, v. 9, n. 2, p. 192-199, 2014.

MALAVOLTA, E.; VITTI, G. C.; OLIVEIRA, S. A. Avaliação do estado nutricional de plantas: princípios e aplicações. Piracicaba: POTAFOS, p. 308, 1997.

MIKKELSEN, R. Ammonia emissions from agricultural operations: fertilizer. Better Crops, v. 93, n. 4, p. 9-11, oct. 2009.

NÖNMIK, H. The effect of pellet size on the ammonia loss from urea applied to Forest soils. Plant and Soil, Dordrecht, v. 39, p. 309-318, 1973.

OTTO, R.; ZAVASCHI, E.; SOUZA NETTO, G. J. M. ; MACHADO, B. D.; MIRA, A. B. de; Ammonia volatilization from nitrogen fertilizers applied to sugarcane straw. Revista Ciência Agronômica, v. 48, n. 3, p. 413-418, 2017.

PEREIRA, H. S. P.; LEÃO, A. F.; VERGINASSI, A.; CARNEIRO, M. A. C. Ammonia volatilization of urea in the out-of-season corn. Revista Brasileira de Ciência do Solo, v. 33, n. 6, p. 1685-1694, 2009.

SHAVIV, A. Controlled release fertilizers. In: International workshop on enhanced-efficiency fertilizers, 1., 2005, Frankfurt. Paris: International Fertilizer Industry Association, 2005. p. 13.

SOUZA, T. L.; GUELFI, D. R.; SILVA, A. L.; ANDRADE, A. B.; CHAGAS, W. F. T.; CANCELLIER, E. L. Ammonia and carbon dioxide emissions by stabilized conventional nitrogen fertilizers and controlled release in corn crop. Revista Ciência e Agrotecnologia, v. 41, n. 5, p. 494-510, 2017. 
TRENKEL, M. E. Slow and controlled-release and stabilized fertilizers: an option for enhancing nutrient efficiency in agriculture. Paris: IFA, 2010. 163 p. Verde: Aldeia Norte Editora, 1998. p. 78-92. 96p.

WATSON, C. J.; AKHONZADA, N. A.; HAMILTON, J. T. G.; MATTHEWS, D. I. Rate and mode of application of the urease inhibitor $\mathrm{N}$-(N-Butyl) thiophosphoric triamide on ammonia volatilization from surface-applied urea. Soil Use and Management, v. 24, p. 246-253, 2008.

Received: July 19, 2018

Accepted: January 17, 2019 